\title{
Knowledge, Attitude and Practice of Voluntary Blood Donation among Physicians in a Tertiary Health Facility of a Developing Country
}

Nwogoh Benedict ${ }^{1 *}$, Aigberadion Usimenahon ${ }^{1}$, Nwannadi Ikenna Alexander ${ }^{2}$ and Aigbe Is $^{3}$

${ }^{1}$ Department of Haematology and Blood Transfusion, University of Benin Teaching Hospital, P.M.B 1111, Benin City, Nigeria

${ }^{2}$ Department of Haematology, Benue State University, Makurdi, Nigeria

${ }^{3}$ Department of Chemical Pathology, Benue State University, Makurdi, Nigeria

\begin{abstract}
Introduction: There is shortage of active blood donors to meet the increased demand. Precisely aimed promotion and information, targeted motivation and selection of non-remunerated healthy volunteer donors are needed for an adequate and safe blood and blood products supply.

Objectives: The objectives of this study are to assess the knowledge, attitude and practice of voluntary blood donation among physician, to identify and recruit potential voluntary blood donors amongst them and to determine the association between blood donation and gender, duration of practice and sub specialty of the physicians.

Methodology: This was a cross sectional qualitative study conducted at the University of Benin Teaching Hospital, Benin City. A pre tested questionnaires was administered to 140 physicians in the tertiary health facility.

Statistical analysis: The responses were collated and analyzed with the Statistical Package for Social Sciences (SPSS) 16. The results are presented in frequency tables. The association between blood donation practice and gender of respondents, duration of practice and specialty of the responding physicians were tested using Chi-square and Fisher's test where appropriate. P-values $<0.05$ were considered significant.
\end{abstract}

Results: Only 58 (41.4\%) physicians have donated with $33(56.9 \%)$ donating less than once a year, $18(31 \%)$ between $1-3$ times a year and $5(8.6 \%)$ more than thrice a year. Most $(53.4 \%)$ donated voluntarily, $39.7 \%$ for a friend or relative, $3.4 \%$ for remuneration and $5.2 \%$ to know their screening status.

Conclusion: Physicians have good knowledge of voluntary donation and have a positive attitude towards donation but there is a disparity in their practice of blood donation.

Keywords: Blood donation; Physicians; Developing country

\section{Introduction}

Blood is scarce; its demand far outweighs the supply. There is shortage of active blood donors to meet the increased demands of blood [1], in addition to limited supply, the issue of safety especially with regard to the risk of transfusion transmissible infection is also an issue of utmost concern especially in the developing countries. Donor blood procurement from voluntary non remunerated donor has been adjudged the safest source of blood. Hence the World Health Organization (WHO) has adopted a policy aimed at $100 \%$ voluntary non-remunerated donor blood procurement by the year 2020 [2].

Precisely aimed promotion and information, targeted motivation and selection of non-remunerated, healthy volunteer repeat donors form the foundation of safe blood products supply in highly developed countries [3]. In most developing and transitional countries, by contrast, family replacement and paid blood donors are still a significant source of blood components for transfusion [4].

The constant concern in the efforts to meet the demands for blood is the fact that only a small percentage of the eligible population actually chooses to donate blood on a regular basis and that a significant percentage of eligible donors are deferred temporarily or permanently because of strict deferral criteria being continuously added in the name of blood safety [5]. At the same time, the demand for blood and blood products in most countries continues to increase because of the rise in human life expectancy and the implementation of new and aggressive surgical and therapeutic methods requiring large quantities of blood and blood products [6].
Physicians by virtue of their training and medical practices are expected to be highly informed on the processes of donor blood procurement and the challenges of supply as well as the potential hazards of transfusion. They also constitute a potential pool of eligible but yet under explored donors. The objectives of this study are to assess the knowledge, attitude and practice of voluntary blood donation among physician, to identify and recruit potential voluntary blood donors amongst them and to determine the association between blood donation and gender, duration of practice and sub specialty of the physicians.

\section{Methodology}

This is a cross sectional qualitative study conducted at the University of Benin Teaching Hospital (UBTH) as part of the 2011 World Blood Donor Day Programme. The hospital is a major referral, training center for both undergraduate and postgraduate doctors in

*Corresponding author: Nwogoh Benedict, Department of Haematology and Blood Transfusion, University of Benin Teaching Hospital, P.M.B 1111, Benin City Nigeria, Tel: 08038955265; E-mail: b.nwogoh@yahoo.com

Received November 23, 2011; Accepted March 07, 2012; Published March 13 2012

Citation: Benedict N, Usimenahon A, Alexander NI, Isi A (2012) Knowledge Attitude and Practice of Voluntary Blood Donation among Physicians in a Tertiary Health Facility of a Developing Country. J Blood Disord Transfus 3:117. doi:10.4172/2155-9864.1000117

Copyright: (c) 2012 Benedict N, et al. This is an open-access article distributed under the terms of the Creative Commons Attribution License, which permits unrestricted use, distribution, and reproduction in any medium, provided the original author and source are credited. 
Citation: Benedict N, Usimenahon A, Alexander NI, Isi A (2012) Knowledge, Attitude and Practice of Voluntary Blood Donation among Physicians in a Tertiary Health Facility of a Developing Country. J Blood Disord Transfus 3:117. doi:10.4172/2155-9864.1000117

Page 2 of 4

various specialties and a research institute in south south Nigeria. It has over 600 physicians, a bulk of which comprise of house officers and resident doctors undergoing postgraduate training. The center operates a hospital-based blood banking system which is highly dependent on blood procurement from vendors who operate paid donor outlets. Their supply is augmented by supply from National Blood Transfusion Service (NBTS), family replacement and very few voluntary donors. Pretested questionnaire were self administered to 140 physicians from various clinical sub specialties. An informed written consent was obtained from all participants.

\begin{tabular}{|c|c|c|}
\hline 1. Age Range (median age) & $25-52(32) y r s$ & \\
\hline 2. Gender & $N=140$ & Percentage (\%) \\
\hline Males & 102 & 72.9 \\
\hline Females & 33 & 23.6 \\
\hline No Response & 5 & 3.6 \\
\hline \multicolumn{3}{|l|}{ 3. Marital Status } \\
\hline Single & 56 & 40.0 \\
\hline Married & 82 & 58.6 \\
\hline No Response & 2 & 1.4 \\
\hline \multicolumn{3}{|l|}{ 4. Professional Status } \\
\hline House Officers & 18 & 12.9 \\
\hline Residents & 115 & 82.1 \\
\hline Medical Officers & 4 & 2.9 \\
\hline No Response & 3 & 2.1 \\
\hline \multicolumn{3}{|l|}{$\begin{array}{l}\text { 5. Duration of Practice in the } \\
\text { facility }\end{array}$} \\
\hline$<1$ year & 27 & 19.3 \\
\hline $1-5$ years & 85 & 60.7 \\
\hline$>5$ years & 26 & 18.6 \\
\hline No response & 2 & 1.4 \\
\hline \multicolumn{3}{|l|}{ 6. Specialty } \\
\hline Dentistry & 15 & 10.7 \\
\hline Surgery & 10 & 7.1 \\
\hline Internal Medicine & 21 & 15 \\
\hline Obstetrics and Gynaecology & 14 & 10 \\
\hline Family Medicine & 9 & 6.4 \\
\hline Anaesthesia & 25 & 17.9 \\
\hline Psychiatry & 4 & 2.9 \\
\hline Paediatrics & 5 & 3.6 \\
\hline Community Medicine & 2 & 1.4 \\
\hline Pathology & 15 & 10.7 \\
\hline Accident and Emergency & 6 & 4.3 \\
\hline No Response & 14 & 10.0 \\
\hline \multicolumn{3}{|l|}{ 7. Religion } \\
\hline Christianity & 131 & 93.6 \\
\hline Moslem & 1 & 0.7 \\
\hline Traditionalist & 1 & 0.7 \\
\hline No Response & 7 & 5.0 \\
\hline Total & 140 & 100 \\
\hline
\end{tabular}

Table 1: Sociodemographic Parameters of Respondents.

\begin{tabular}{|l|l|}
\hline Blood Group & N (\%) \\
\hline A & $21(22.8)$ \\
\hline B & $13(14.1)$ \\
\hline AB & $5(5.4)$ \\
\hline O & $53(57.6)$ \\
\hline Rhesus D Positive & $84(91.3)$ \\
\hline Rhesus Negative & $8(8.7)$ \\
\hline
\end{tabular}

Table 2: Summary of Blood Group of Respondents.

\begin{tabular}{|c|c|c|c|}
\hline $\begin{array}{l}\text { Do you know the com- } \\
\text { mon blood groups? }\end{array}$ & & $\begin{array}{l}\text { Who should donate } \\
\text { blood? }\end{array}$ & \\
\hline Yes & $138(98.6 \%)$ & Men & $136(97.1 \%)$ \\
\hline No & $1(0.7 \%)$ & Women & $125(89.3 \%)$ \\
\hline No Response & $1(0.7 \%)$ & Young (<18yrs) & $8(5.7 \%)$ \\
\hline $\begin{array}{l}\text { Do you know your } \\
\text { blood group? }\end{array}$ & & Old (> 60yrs) & $5(3.6 \%)$ \\
\hline Yes & 139(99.3\%) & Vulnerable group & $11(7.9 \%)$ \\
\hline No Response & $1(0.7 \%)$ & Healthy & $102(72.9 \%)$ \\
\hline $\begin{array}{l}\text { Blood group of Re- } \\
\text { spondent? }\end{array}$ & & Diseased & $1(0.7 \%)$ \\
\hline A Negative & $2(1.4 \%)$ & $\begin{array}{l}\text { Who should not donate } \\
\text { blood? }\end{array}$ & \\
\hline A Positive & $19(13.6 \%)$ & Men & $6(4.3 \%)$ \\
\hline AB Positive & $5(3.6 \%)$ & Woman & $8(5.7 \%)$ \\
\hline B Negative & $1(0.7 \%)$ & Young (<18yrs) & $61(43.6 \%)$ \\
\hline B Positive & $12(8.6 \%)$ & Old (> 60yrs) & $92(65.7 \%)$ \\
\hline O Negative & $5(3.8 \%)$ & Vulnerable group & $106(75.7 \%)$ \\
\hline O Positive & $48(34.3 \%)$ & Healthy & $4(2.9 \%)$ \\
\hline Invalid & $2(1.4 \%)$ & Diseased & $97(69.3 \%)$ \\
\hline No Response & $46(32.9 \%)$ & Culture belief & $5(3.6 \%)$ \\
\hline $\begin{array}{l}\text { Can a person be } \\
\text { infected by receiving } \\
\text { blood transfusion? }\end{array}$ & & Religious belief & $11(7.9 \%)$ \\
\hline Yes & $134(95.7 \%)$ & No Response & $2(1.4 \%)$ \\
\hline No & $5(3.6 \%)$ & $\begin{array}{l}\text { What volume of blood } \\
\text { is collected during } \\
\text { each donation? }\end{array}$ & \\
\hline No Response & $1(0.7 \%)$ & $\leq 500 \mathrm{mls}$ & $85(60.7 \%)$ \\
\hline $\begin{array}{l}\text { What diseases are } \\
\text { transmissible by } \\
\text { blood transfusion? }\end{array}$ & & $500-1000 \mathrm{mls}$ & $48(34.3 \%)$ \\
\hline HIV & 139(99.3\%) & Don't know & $30(21.4 \%)$ \\
\hline HBV & $137(97.9 \%)$ & Invalid & $1(0.7 \%)$ \\
\hline $\mathrm{HCV}$ & $103(73.6 \%)$ & No Response & $2(1.4 \%)$ \\
\hline Syphilis & $60(42.9 \%)$ & $\begin{array}{l}\text { What is the duration of } \\
\text { a donation process? }\end{array}$ & \\
\hline Malaria & $27(19.3 \%)$ & $<20$ minutes & $42(30 \%)$ \\
\hline CMV & $4(2.9 \%)$ & $20-60$ minutes & 67 (47.9\%) \\
\hline Others & $3(2.1 \%)$ & Don't know & $30(21.4 \%)$ \\
\hline $\begin{array}{l}\text { How often can an } \\
\text { individual donate? }\end{array}$ & & No Response & $1(0.7 \%)$ \\
\hline Weekly & $5(3.6 \%)$ & & \\
\hline Monthly & $16(11.4 \%)$ & & \\
\hline 3 Monthly & $50(35.7 \%)$ & & \\
\hline 6 Monthly & $49(35 \%)$ & & \\
\hline Annually & $2(1.4 \%)$ & & \\
\hline Don't know & $13(9.3 \%)$ & & \\
\hline Invalid & $1(0.7 \%)$ & & \\
\hline No Response & $4(2.9 \%)$ & & \\
\hline
\end{tabular}

Table 3: Knowledge on blood donation

\section{Statistical Analysis}

The responses were collated and analyzed with the Statistical Package for Social Sciences (SPSS) 16. The results are presented in frequency tables. The association between blood donation practice and gender of respondents, duration of practice and specialty of the responding physicians were tested using Chi-square and Fisher's test where appropriate. P-values $<0.05$ were considered significant.

\section{Results}

There were 140 respondents in the age range of 25-52years (median 


\begin{tabular}{|c|c|c|c|}
\hline $\begin{array}{l}\text { SECTION C: Attitude } \\
\text { towards blood donation }\end{array}$ & & $\begin{array}{l}\text { SECTION D: Practice } \\
\text { of blood donation }\end{array}$ & \\
\hline $\begin{array}{l}\text { What do think about } \\
\text { blood donation? }\end{array}$ & $N(\%)$ & $\begin{array}{l}\text { Have you donated } \\
\text { before? }\end{array}$ & $\mathrm{N}(\%)$ \\
\hline Good & $125(89.3)$ & Yes & $58(41.4)$ \\
\hline Bad & $2(1.4)$ & No & $82(58.6)$ \\
\hline Neutral & $10(7.1)$ & $\begin{array}{l}\text { How often do you } \\
\text { donate? }\end{array}$ & \\
\hline No Response & $3(2.1)$ & $<1$ time a year & $33(56.9)$ \\
\hline $\begin{array}{l}\text { What do you think is the } \\
\text { best source of donor } \\
\text { blood? }\end{array}$ & & 1 - 3 times a year & $18(31.0)$ \\
\hline Voluntary donor & $113(80.7)$ & $>3$ times a year & $5(8.6)$ \\
\hline Replacement donor & $10(7.1)$ & No response & $2(3.4)$ \\
\hline Remunerated donor & $1(0.7)$ & Why did you donate? & \\
\hline Self donor & $3(2.1)$ & $\begin{array}{l}\text { A friend or relative } \\
\text { needed blood }\end{array}$ & $23(39.7)$ \\
\hline Invalid & $11(7.9)$ & Voluntary & $31(53.4)$ \\
\hline No Response & $2(1.4)$ & Remuneration & $2(3.4)$ \\
\hline $\begin{array}{l}\text { Can something happen to } \\
\text { a blood donor during or } \\
\text { after donation? }\end{array}$ & & $\begin{array}{l}\text { To know my screen- } \\
\text { ing status }\end{array}$ & $3(5.2)$ \\
\hline Yes & $117(83.6)$ & $\begin{array}{l}\text { Will you donate if } \\
\text { called upon or re- } \\
\text { minded to do so? }\end{array}$ & \\
\hline No & $14(10)$ & Yes & $80(57.1)$ \\
\hline I don't know & $7(5.0)$ & No & $35(25.0)$ \\
\hline No Response & $2(1.4)$ & No Response & $25(17.9)$ \\
\hline $\begin{array}{l}\text { What can happen to a } \\
\text { blood donor during or } \\
\text { after donation? }\end{array}$ & & $\begin{array}{l}\text { Number of those who } \\
\text { stated their contact }\end{array}$ & $32(40.0)$ \\
\hline Contract Infection & $13(11.1)$ & $\begin{array}{l}\text { Reasons for non do- } \\
\text { nation by non-donors }\end{array}$ & \\
\hline Temporary Weakness & $108(92.3)$ & $\begin{array}{l}\text { Not approached to } \\
\text { donate }\end{array}$ & $26(31.7)$ \\
\hline Fall Sick & $9(7.7)$ & Unfit to donate & $14(17.1)$ \\
\hline $\begin{array}{l}\text { Should patient relatives } \\
\text { be asked to donate? }\end{array}$ & & $\begin{array}{l}\text { Need to donate for } \\
\text { friends or relatives in } \\
\text { future }\end{array}$ & $18(22)$ \\
\hline Yes & $127(90.7)$ & Fear of needles & $10(12.2)$ \\
\hline No & $5(3.6)$ & $\begin{array}{l}\text { Fear of knowing my } \\
\text { status }\end{array}$ & $2(2.4)$ \\
\hline I don't know & $1(0.7)$ & $\begin{array}{l}\text { Donated blood may } \\
\text { be sold }\end{array}$ & $4(4.9)$ \\
\hline \multirow[t]{5}{*}{ No Response } & $7(5.0)$ & No Response & $17(20.7)$ \\
\hline & & $\begin{array}{l}\text { Do you encourage } \\
\text { relatives to donate? }\end{array}$ & \\
\hline & & Yes & $126(90.0)$ \\
\hline & & No & $8(5.7)$ \\
\hline & & No Response & $6(4.3)$ \\
\hline
\end{tabular}

Table 4: Attitude and Practice of Blood Donation.

age was 32 years) with an M: F of 3:1. Fifty eight percent (82) were married and $56(40 \%)$ single. Most of the respondents were resident doctors in various specialties of training. They accounted for $82.1 \%$ of respondent. Majority of the physicians have been practicing in the facility for 1-5 years. Physicians from 11 departments including dentistry (10.7\%), surgery (7.1\%), internal medicine (15\%), obstetrics and gynaecology (10\%), family medicine $(6.4 \%)$, anaesthesia $(17.9 \%)$, psychiatry $(2.9 \%)$, paediatrics $(3.6 \%)$, community medicine $(1.4 \%)$, pathology (10.7\%) and accident and emergency (4.3\%) responded. Most of the respondents were Christians accounting for 93.6\%. Table 1 show details of the demographics of respondent.

On knowledge, the respondents expressed a good knowledge of the common blood group types and of their own blood group. The blood group of respondent are A Rhesus(Rh) negative (1.4\%), A Rh positive (13.6\%), AB Rh positive (3.6\%), B Rh negative (0.7\%), O Rh negative (3.8\%) and O Rh positive (34.3\%). Forty six (32.9\%) did not respond to question on knowledge of their blood group (Table 2).

Most respondent (95.7\%) are aware of the risk of transmission of infection by transfusion. The risk of transmission of HIV, HBV, HCV and Syphilis was affirmed by $99.3 \%, 97.9 \%, 73.6 \%$ and $42.9 \%$ while $19.3 \%$ and $2.9 \%$ affirmed those of malaria and CMV respectively. Thirty five percent stated that the minimum donation frequency was 6 months, $35.7 \%$ tri-monthly, $11.4 \%$ monthly while $9.3 \%$ had no knowledge of this. About $8 \%$ and $3.6 \%$ stated that people should not donate for religious and cultural beliefs respectively. On knowledge of volume of blood collected in each process $60.7 \%$ stated less than 500 $\mathrm{mls}, 34.3 \%$ ticked $500-1000 \mathrm{mls}$ while $21.4 \%$ express no knowledge of it. Table 3 shows the details of the knowledge of blood donation expressed by respondents.

A hundred and twenty five (89.3\%) respondents said blood donation is good. Voluntary donation was accepted as the best source of donor blood by $80.7 \%$, replacement donors by $7.1 \%$, remunerated by $0.7 \%$ and self donation by $2.1 \%$. One hundred and seventeen $(83.6 \%)$ said something can happen to a donor, $11.1 \%, 92.3 \%$ and $7.6 \%$ stated that a donor might contract infection, become temporary weak and suffer loss of health respectively.

Only 58 (41.4\%) physicians have donated with 33 (56.9\%) donating less than once a year, 18 (31\%) between 1-3 times a year and $5(8.6 \%)$ more than thrice a year. Most (53.4\%) donated voluntarily, $39.7 \%$ for a friend or relative, $3.4 \%$ for remuneration and $5.2 \%$ to know their screening status. Eighty (57.1\%) accepted to be reminded or called upon to donate but only $40 \%$ of them left their contacts.

Eighty two (58.6\%) had never donated. Reasons for non donation included $26(31.7 \%)$ not approached to donate, 18 (22\%) need to donate for friends or relatives in the future, 14 (17.1\%) not fit to donate, $10(12.2 \%)$ fear of needles, 4 (2.9\%) blood may be sold by the blood bank, 2 (2.4\%) fear of knowing their status. One hundred and twenty seven $(90.7 \%)$ thought that patient relatives should be encouraged to donate and (126) $90 \%$ actually encouraged relatives to donate. Table 4 Section D show details of blood donation practices among physicians.

There was no significant association between donation practices and gender, duration of practice in the facility and specialty of physicians as $P$ values were $0.227,0.613$ and 0.844 respectively (Table 5 and 6).

\section{$\mathrm{X}^{2}=0.980 \mathrm{P}=0.613$}

\begin{tabular}{|c|c|c|c|}
\hline Gender & Donors & Non-donors & Total \\
\hline Males & 43 & 59 & 102 \\
\hline Females & 10 & 23 & 33 \\
\hline Total & 53 & 82 & 135 \\
\hline
\end{tabular}

$\mathrm{X}^{2}=0.114, \mathrm{P}=0.227$

Table 5: The association between gender and blood donation.

\begin{tabular}{|c|c|c|c|}
\hline Duration of Practice & Donors & Non-donors & Total \\
\hline$<1$ years & 10 & 17 & 27 \\
\hline $1-5$ years & 35 & 50 & 85 \\
\hline$>5$ years & 13 & 13 & 26 \\
\hline Total & 58 & 80 & 138 \\
\hline
\end{tabular}

Table 6: The association between duration of practice and blood donation 


\section{Discussion}

There are limited studies on voluntary blood donation practices among physicians. By training they have been taught and are continually exposed to current articles on transfusion practices. They are the ones who request, utilize and manage problems arising from use of blood and blood products. The extent these knowledge influence their practice of blood donation is yet to be fully ascertained. All respondents were within the eligible age group for blood donation hence they constitute a pool of potential donors [7]. The blood group $\mathrm{ABO}$ and Rhesus phenotypic patterns of respondent were similar to reports of previous work done in the geographic location [8]. Blood group $\mathrm{O}$ was the commonest (57.6\%) while $\mathrm{AB}$ was the least $(5.4 \%)$. The frequency of $\mathrm{Rh} \mathrm{D}$ negative phenotype was $8.7 \%$ similar to the findings by Enosolease and Bazuaye [8]. As expected the respondent displayed a high knowledge with regard to common blood group, common transfusion transmissible infections though less than average recognized syphilis, CMV and other rare infectious agent transmissible by blood. This may be attributed to a decline in the screening for syphilis by the local blood bank and non inclusion of malaria and CMV screening for donors. Effect of culture and religion was recognized as a limitation to donation. Some Christian sects still object strongly to blood and blood product usage despite the absence of a perfect substitute. There was limited knowledge on frequency of donation and duration of a donation process. This may be due to the fact that less than $50 \%$ have donated blood.

Physicians usually request for blood and blood components for their patients and it is expected that they should be conversant with the challenges of blood procurement. Hence it is surprising therefore that "not been approached for blood donation" is the commonest reason for non-donation.

A study from the Blood Centre of Umea University Hospital in Sweden showed that among motives for donating blood, healthcare occupation represented only $7.7 \%$ of the donors [9]. Misje et al. [10] from the Blood Bank of Oslo, Norway, found that $12.4 \%$ of their donors worked in health and social sciences, a percentage smaller than that of the total work force (17.6\%). These authors expressed surprise that healthcare professionals were under-represented.

In a similar study conducted in an academic based hospital in Virginia USA, of 687 survey respondents, only 21 (3.1\%) were physicians [11]. The returning physician donors (16) came back a median of 12 months after a prior donation, a lapse 9 months longer than for all returning donors (median 3 months). One-third (33.3\%) of physician donors presented as walk-in donors, two times that of the total survey respondents (16.2\%) in the Virginia study.

Gilani et al. [12] in a comparative study on blood donation by medical and paramedical workers reported $49.2 \%$ of doctors as donors and only $3.4 \%$ of these regular donors.

In this study, we recorded $41.4 \%$ blood donation by physicians, $39.6 \%$ were regular donors and $53.4 \%$ of these were voluntary. Eighty (57.1\%) accepted to be recruited and reminded to donate only $40 \%$ of them wrote their contacts. This was a far cry from the knowledge and attitude indicated by the questionnaire. Voluntary blood donation among physicians though low generally, doctors in this study performed higher than their colleagues in the developed countries as documented in the studies by Gilani et al. [12] and Kanner et al. [11]. There is need to properly harness this potential pool of donors if the drive for $100 \%$ voluntary donor targeted by the WHO will be achieved.
For a sustainable blood banking system aimed at providing adequate and safe blood to all in need, a proper sensitization, and massive donor recruitment from all potential donors must be implemented.

\section{Conclusion}

Physicians in the study centre have good knowledge of voluntary donation and have a positive attitude towards donation but there is a disparity in their practice of blood donation.

\section{References}

1. Gillespie TW, Hillyer CD (2002) Blood donors and factors impacting the blood donation decision. Transfus Med Rev 16: 115-130.

2. http://www.who.int/mediacentre/factsheets/fs279/en/

3. Seifried E, Mueller MM (2011) The Present and the Future of Transfusion Medicine. Blood Transfus 9: 371-376.

4. Enosolease ME, Imarengiaye CO, Awodu OA (2004) Donor blood procurement and utilization at the University of Benin Teaching Hospital, Benin City. Afr J Reprod Health 8: 59-63.

5. http://www.wpro.who.int/mediacentre/factsheets/fs20040610.htm

6. Riley W, Schwei M, McCullough J (2007) The United States potential blood donor pool: estimating the prevalence of donor-exclusion factors on the pool of potential donors. Transfusion 47: 1180-1188.

7. Widmann FK (1993) Standards for Blood Bank and Transfusion Services. (15thedn), American Association of Blood banks, Bethesda, MD.

8. Enoselease ME, Bazuaye GN (2008) Distribution of ABO and Rh-D blood groups in the Benin area of Niger-Delta: Implication for regional blood transfusion. Asian J Transfus Sci 2: 3-5.

9. Sojka BN, Sojka P (2008) The blood donation experience: self-reported motives and obstacles for donating blood. Vox Sang 94: 56-63.

10. Misje AH, Bosnes V, Gasdal O, Heier HE (2005) Motivation, recruitment and retention of voluntary non-remunerated blood donors: a survey-based questionnaire study. Vox Sang 89: 236-244.

11. Kanner WA, Jeffus S, Wehrli G (2009) An academic-based hospital donor site: Do Physicians Donate Blood? Ann Clin Lab Sci 39: 339-344.

12. Gilani I, Kayani ZA, Atique M (2007) Knowledge, attitude and practices regarding blood donation prevalent in medical and paramedical personnel. Coll Physicians Surg Pak 17: 473-476. 